\begin{tabular}{ccc}
\hline & \begin{tabular}{c} 
JURNAL BIOTERDIDIK: WAHANA EKSPRESI ILMIAH \\
e-ISSN: \\
$2621-5594$ \\
p-ISSN: \\
$2302-1276$ \\
\hline
\end{tabular} & \\
\hline Vol. 9 No. 3, Desember 2021, page. 202-216 & http://jurnal.fkip.unila.ac.id/index.php/JBT/ \\
\hline
\end{tabular}

\title{
Struktur Dan Komposisi Vegetasi Mangrove Di Kawasan Laguna Segara Anakan Cilacap
}

\author{
Dewi Kresnasari $^{1^{*}}$, Arbi Mei Gitarama ${ }^{2}$ \\ ${ }^{1}$ Program Studi Ilmu Perikanan, Universitas Nahdlatul Ulama Purwokerto, Purwokerto Selatan, Indonesia \\ ${ }^{2}$ Institut Teknologi dan Sains Nahdlatul Ulama Losarang, Indramayu, Indonesia \\ *e-mail: dewiks2903@gmail.com
}

Received: October 31, 2021

Accepted: December 24, 2021

Online Published: December 30, 2021

\begin{abstract}
Structure and Material of Mangrove Vegetation in the Cilacap Segara Anakan Lagoon Area. In coastal areas, mangrove communities have many functions economically, physically, and ecologically. One of the mangrove forest areas that is experiencing rapid decline in area is the Segara Anakan Lagoon, Cilacap. The purpose of this study was to determine the structure and composition of mangrove vegetation. Vegetation data was collected by purposive sampling method and each station was made 9 sampling plots. The results found that there are 12 species consisting of 4 major mangrove families, 1 minor mangrove family and 2 associated mangrove families. In general, the mangrove tree vegetation in the eastern part of Segara Anakan is dominated by Aegiceras corniculatum with an INP ranging from 38.99$67.23 \%$, the middle part is dominated by Nypa fruticans with an INP ranging from 47.80$70.18 \%$ and the western part is dominated by Sonneratia alba with an INP of $56.32 \%$. Environmental quality measures include water temperature, salinity, dissolved oxygen, soil $\mathrm{pH}$, water $\mathrm{pH}$, TSS, total soil $\mathrm{N}$, organic $C$, soil phosphate still support mangrove life.
\end{abstract}

Keywords: density, Diversity Index $\left(H^{\prime}\right)$, Important Value Index (INP), mangrove, Segara Anakan

Abstrak: Struktur Dan Bahan Vegetasi Mangrove Di Kawasan Laguna Segara Anakan Cilacap. Pada kawasan pesisir, komunitas mangrove memiliki banyak fungsi secara ekonomi, fisik maupun ekologis. Salah satu kawasan hutan mangrove yang mengalami penurunan luasan dengan cepat adalah Laguna Segara Anakan, Cilacap. Tujuan penelitian ini yaitu mengetahui struktur dan komposisi vegetasi mangrove. Pengambilan data vegetasi dilakukan dengan metode purposive sampling dimana setiap stasiun dibuat 9 plot sampling. Hasil penelitian ditemukan 12 spesies mangrove yang terdiri dari 4 famili mangrove mayor, 1 famili mangrove minor dan 2 famili mangrove asosiasi. Secara umum, vegetasi pohon mangrove pada Segara Anakan bagian timur didominansi oleh Aegiceras corniculatum dengan INP berkisar 38,99-67,23\%, bagian tengah didominansi oleh Nypa fruticans dengan INP berkisar 47,80-70,18\% dan bagian barat didominansi oleh Sonneratia alba dengan INP 56,32\%. Pengukuran kualitas lingkungan meliputi suhu air, salinitas, oksigen terlarut, $\mathrm{pH}$ tanah, $\mathrm{pH}$ air, TSS, $\mathrm{N}$ total tanah, C-organik, Pospat tanah masih mendukung kehidupan mangrove.

Kata kunci: mangrove, Indeks Keanekaragaman (H'), Indeks Niai Penting (INP), kerapatan, Segara Anakan 


\section{PENDAHULUAN}

Ekosistem mangrove atau hutan bakau termasuk wilayah yang sangat unik dan khas. Sekelompok vegetasi tersebut hanya tumbuh di daerah pasang surut pantai tropis dan subtropis. Mangrove dapat tumbuh subur di daerah pantai dekat muara sungai dan pantai yang terlindung dari kekuatan ombak (Pratama\&Isdianto, 2017). Pada ekosistem pesisir, hutan mangrove menduduki peranan yang sangat penting. Beberapa fungsi mangrove tidak dapat digantikan oleh ekosistem atau tanaman lainnya. Secara fisik hutan mangrove berfungsi sebagai pemecah ombak secara alami, mencegah terjadinya erosi dan abrasi, peredam angin, penghambat intruisi air laut, penjebak sedimen yang menjadikan wilayah daratan mampu terus bertambah menuju laut. Selain itu beberapa sumberdaya ikan memanfaatkan ekosistem ini sebagai daerah pemijahan (spawning ground), daerah asuhan (nursery ground), serta sebagai tempat mencari makan (feeding ground) (Fitriah et al., 2013; Rosadi et al., 2018). Oleh karena itu secara tidak langsung kehidupan manusia tergantung pada keberadaan ekosistem mangrove. Meskipun demikian, ekosistem mangrove merupakan salah satu sumberdaya alam yang tidak terlepas dari tekanan dan pemanfaatan secara berlebihan. Salah satu kawasan hutan mangrove yang mengalami penurunan luasan dengan cepat adalah wilayah laguna Segara Anakan, Kabupaten Cilacap.

Hutan mangrove Segara anakan mengalami perubahan dari tahun 2000-2015. Penutup lahan non mangrove berubah menjadi mangrove sebanyak 1.058 ha, akan tetapi mangrove juga berubah fungsi menjadi penggunaan lahan lainnya mencapai 1.821 ha (Dwininta\&Hartono,2017). Perubahan tersebut terjadi karena faktor alami (sedimentasi) dan faktor antropogenik. Selama 38 tahun (1978-2016) telah terjadi penyusutan luas area perairan sebesar 2.703,7 ha atau adanya laju penambahan area daratan pada Laguna besar 71.15 ha/th. Pada laguna Segara Anakan bagian barat lebih terdapak efek sedimentasi yaitu memiliki kedalaman dangkal $(<2 \mathrm{~m})$. Hal ini dikarenakan bagian barat kawasan tersebut sebagai muara Sungai Citanduy, Cibeureum dan Cikonde serta sebagian kecil berasal dari sedimentasi pantai (Dewi et al., 2016).

Perubahan kondisi ini tentu saja akan mempengaruhi struktur komunitas hutan mangrove yang ada di Segara Anakan. Penelitian terdahulu menggambarkan bahwa Segara Anakan mengalami perubahan luasan hutan mangrove dan menurunnya komposisi jenis mangrove dengan beragam faktor diantaranya sedimentasi dan alih fungsi lahan (Ananta et al., 2020; Hilmi et al., 2019; Koswara et al., 2017; Suryono, 2015). Oleh karena itu perlu adanya penelitian secara berkala berkaitan komposisi jenis mangrove di wilayah tersebut sehingga dapat dijadikan referensi bagi pemerintah dan warga setempat untuk melestarikan ekosistem mangrove Segara Anakan menjadi lebih baik. Penelitian ini bertujuan untuk menggambarkan struktur dan komposisi mangrove di Segara Anakan, Cilacap.

\section{METODE}

Penelitian dilakukan pada bulan Juli-September 2021 di hutan mangrove kawasan Laguna Segara Anakan, Cilacap. Teknik pengambilan sampel menggunakan metode purposive sampling. Stasiun pengambilan sampel yaitu hutan mangrove Segara Anakan bagian timur (St 1), bagian tengah (St 2) dan bagian barat (St 3). Pengidentifikasian jenis mangrove dan pengukuran mangrove dilakukan secara langsung di lapangan. Sampel sedimen dianalisis di Laboratorium Tanah/Sumberdaya Lahan, Universitas Jenderal Soedirman. 

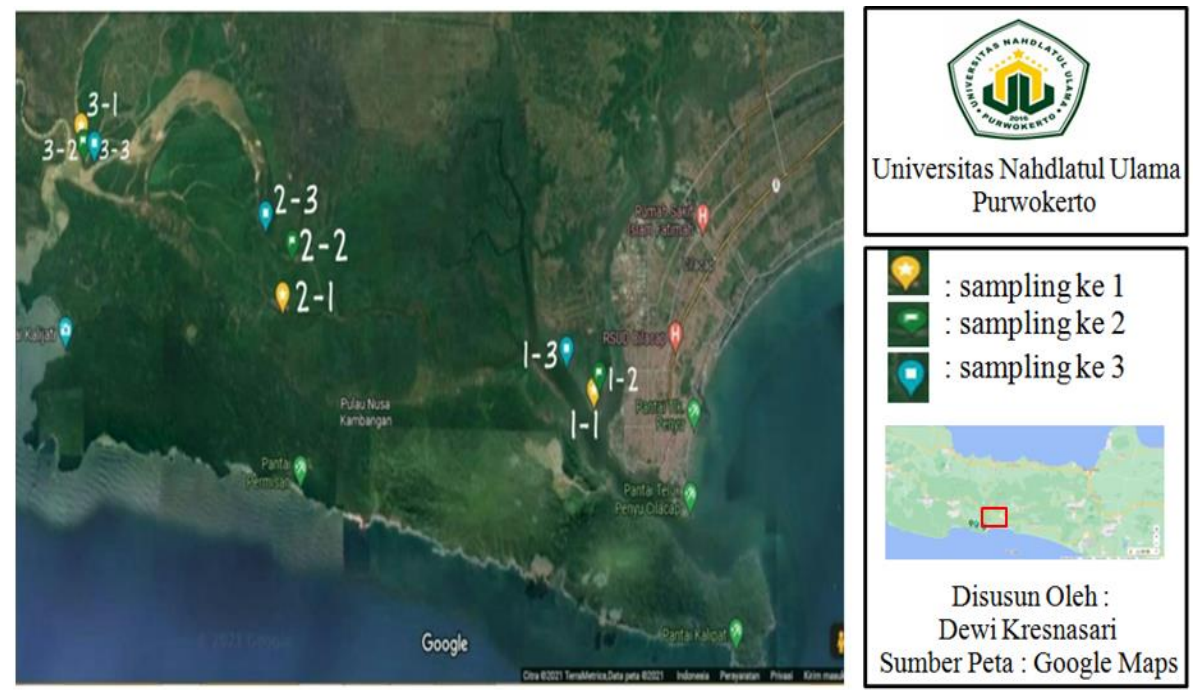

Gambar 1. Peta Lokasi Penelitian

Peralatan yang digunakan pada penelitian ini adalah alat tulis, tali rafia, gunting dan pisau, buku identifikasi mangrove (Noor et al., 2006), Global Positioning System (GPS), kantong plastic, meteran, dan kamera digital. Bahan yang digunakan dalam penelitian ini adalah sampel tanah, kertas label, lakban, tisu.

Pengukuran kerapatan mangrove ditentukan dengan cara menggunakan plot sebanyak sembilan buah. Transek ukuran $10 \mathrm{~m}$ x $10 \mathrm{~m}$ untuk pengukuran mangrove kategori pohon, transek ukuran $5 \mathrm{~m}$ x $5 \mathrm{~m}$ untuk kategori anakan, dan untuk semai memiliki ukuran transek $1 \mathrm{~m}$ x $1 \mathrm{~m}$ (Bengen, 2000).

Pengukuran peranan mangrove terhadap suatu ekosistem dilakukan dengan cara menghitung Indeks Nilai Penting (INP) dari setiap mangrove yang telah teridentifikasi. Indeks Nilai Penting (INP) untuk kategori pohon dan sapling yaitu penjumlahan nilai kerapatan relatif (RKi) dan penutupan relatif (RDi) (Mishbach et al., 2018), sedangkan kategori semai penjumlahan nilai kerapatan relatif (RKi) dan frekuensi relatif (RFi) (Onrizal, 2008).

Indeks Keanekaragaman (H')

Keanekaragaman mangrove dihitung dengan menggunakan rumus keanekaragaman Shannon-Wiener (Bengen, 2000), sebagai berikut:

$H^{s}=-\sum_{i=1}^{n}\left(\frac{n i}{N}\right) \ln \left(\frac{n i}{N}\right)$

Keterangan :

$\mathrm{H}^{\prime} \quad$ : Indeks Keanekaragaman Shannon-Wienner.

$\mathrm{Ni}$ : Jumlah individu setiap jenis i.

$\mathrm{N}$ : Total individu semua jenis.

Hasil yang didiperoleh kemudian dapat dikategorikan yaitu:

- Jika H' $<1$ maka indek keanekaragaman dikategorikan Rendah.

- Jika $1<\mathrm{H}^{\prime}<3$ maka indek keanekaragaman dikategorikan Sedang.

- Jika hasil H'> 3 maka indek keanekaragaman dikategorikan Tinggi 


\section{HASIL DAN PEMBAHASAN}

Susunan dan betuk vegetasi mangrove secara kuantitatif diketahui dengan cara melakukan sutu analisis vegetasi. Berdasarkan hasil penelitian ditemukan 12 spesies mangrove yang dapat dikelompokan menjadi tiga komponen yaitu komponen mayor, minor dan asosiasi (Noor et al., 2006). Pada komponen mayor terdapat 4 famili yaitu Avicenniaceae, Rhizophoraceae, Sonneratiaceae dan Palmae. Sedangkan komponen minor terdapat 1 famili yaitu Myrsinaceae. Selanjutnya pada komponen asosiasi terdapat 2 famili yaitu Acanthaceae dan Leguminosae (Tabel 1). Sesuai dengan penelitian Ananta et al., (2020) dan Hilmi et al., (2020) beberapa spesies mangrove yang sering ditemukan di muara sungai bagian timur kawasan Segara Anakan yaitu Rhizophora apiculata, Bruguiera gymnorrhiza, Aegiceras corniculatum, Avicennia marina, Avicennia alba, Ceriops tagal, Ceriops decandra, Sonneratia caseolaris, Sonneratia alba, Scyphiphora hydrophyllacea, Xylocarpus moluccensis, Xylocarpus granatum, Talipariti tiliaceum dan Nypa fruticans. Meskipun demikian jenis mangrove yang terdapat di Segara Anakan lebih tinggi dibandingkan daerah Bangka Barat sebanyak 9 spesies (Rosalina \& Rombe, 2021) dan Pantai Mertasari Denpasar sebanyak 5 spesies (Dewi et al., 2017).

Tabel 1. Komposisi Vegetasi Hutan Mangrove Segara Anakan, Cilacap

\begin{tabular}{|c|c|c|}
\hline $\begin{array}{l}\text { Komponen } \\
\text { Mayor }\end{array}$ & Famili & Spesies \\
\hline \multirow[t]{9}{*}{ Mayor } & Avicenniaceae & Avicennia alba Blume \\
\hline & & Avicennia marina (Forsk.) Vierh \\
\hline & Rhizophoraceae & Ceriops tagal(Perr.) C. B. Robinson \\
\hline & & Rhizophora mucronata Lamk \\
\hline & & Rhizophora apiculata $\mathrm{BL}$ \\
\hline & & Bruguiera gymnorrhiza \\
\hline & Sonneratiaceae & Sonneratia alba J. Smith \\
\hline & & Sonneratia caseolaris (L.) Engler \\
\hline & Palmae & Nypa fruticans (Thunb.) Wurmb \\
\hline Minor & Myrsinaceae & Aegiceras corniculatum (L.) Blanco \\
\hline Asosiasi & $\begin{array}{l}\text { Acanthaceae } \\
\text { Leguminosae }\end{array}$ & $\begin{array}{l}\text { Acanthus ilicifolius } \mathrm{L} \\
\text { Derris trifoliata Lour. }\end{array}$ \\
\hline
\end{tabular}

Hasil pengamatan distribusi spesies mangrove menunjukan bahwa rata-rata jenis Rhizophora mucronata, Rhizophora apiculata, Aegiceras corniculatum dapat dijumpai di seluruh lokasi penelitian (Tabel 2). Hal ini diduga spesies tersebut memiliki daya regenerasi dan adaptasi yang tinggi terhadap perubahan lingkungan. Berdasarkan hasil penelitian Irwan et al., (2019) salah satu penyebab Rhizophora sp mempunyai sebaran yang merata di wilayah pesisir Kabupaten Bone yaitu memiliki sifat vivipar. Biji dari spesies tersebut dapat tumbuh menjadi kecambah saat buah masih menempel di pohon induk. Hal ini menyebabkan spesies Rhizopora sp memiliki kesempatan hidup lebih tinggi serta dapat tersebar luas dengan bantuan arus air laut. Di tempat yang berbeda, pada Kabupaten Supiori diperoleh hasil Famili Rhizophoraceae paling mendominansi jumlah dan jenisnya (Warpur, 2018). Melimpahnya jenis Rhizophora juga terdapat di ekosistem mangrove Sungai Pancur, Kabupaten Bangka Barat disebabkan kemampuan adaptasi yang tinggi terhadap perubahan kondisi lingkungan seperti salinitas, substrat, $\mathrm{pH}$ dan suhu yang mendukung bagi pertumbuhan hidup mangrove tersebut (Rosalina \& Rombe, 2021). Pada Stasiun 3 kondisi mangrove lebih heterogen dibanding Stasiun 1 
dan Stasiun 2. Ini diduga bahwa St 3 merupakan suatu habitat yang dapat diterima untuk berbagai jenis spesies mangrove. Keadaan ekosistem mangrove sejati yang heterogen disuatu wilayah menurut Agustini et al., (2016) disebabkan kondisi lingkungan baik substrat maupun salinitas masih bisa ditoleransi oleh berbagai jenis tumbuhan mangrove.

Struktur vegetasi mangrove menurut Bengen (2000), pada umum terdapat zonasi pada area tumbuhnya. Vegetasi Avicennia spp. biasanya berasosiasi dengan Sonneratia spp. Wilayah tumbuhnya di daerah paling dekat dengan laut. Lebih menuju ke darat, biasanya didominasi oleh Rhizophora spp. Di wilayah ini dapat dijumpai Bruguiera spp. dan Xylocarpus spp. Zona berikutnya ke arah lebih darat lagi didominasi oleh Bruguiera spp. Wilayah peralihan antara hutan mangrove dengan hutan dataran rendah biasa ditumbuhi oleh Nypa fruticans (Nipah), dan beberapa species palem lainnya. Akan tetapi, sistem zonasi vegetasi mangrove pada Segara Anakan tidak berlaku. Pernyataan serupa oleh Djohan, (2012); Hilmi et al., (2015); Ratini et al., (2016) bahwa kawasan mangrove Segara Anakan tidak memiliki pola zonasi vegetasi. Selain di Segara Anakan, tidak adanya pola zonasi pada ekosistem mangrove ditemukan pada Kelurahan Mangunharjo, Kabupaten Semarang. Wilayah bibir pantai hingga daratan didominansi oleh Avicennia sp. dan Rhizopora sp. (Tefarani et al., 2019).

Tabel 2. Distribusi Vegetasi Mangrove Pada Lokasi Penelitian

\begin{tabular}{lccc}
\hline \multicolumn{1}{c}{ Nama pohon } & \multicolumn{3}{c}{ Sebaran } \\
\cline { 2 - 4 } & St 1 & St 2 & St 3 \\
\hline Aegiceras corniculatum & + & + & + \\
Bruguiera gymnorrhiza & + & + & - \\
Rhizophora mucronata & + & + & + \\
Rhizophora apiculata & + & + & + \\
Ceriops tagal & + & - & + \\
Nypa fruticans & + & + & + \\
Avicennia marina & - & + & + \\
Avicennia alba & - & - & + \\
Sonneratia alba & - & + & + \\
Sonneratia caseolaris & - & - & + \\
\hline Keterangan: St 1 Stasi
\end{tabular}

Keterangan: St 1 = Stasiun 1; St 2 = Stasiun 2; St 3 = Stasiun 3

Indeks Nilai Penting Vegetasi Mangrove Tingkat Pohon. Indeks Nilai Penting (INP) bertujuan memberikan gambaran kondisi ekologis suatu spesies dalam suatu komunitas vegetasi atau menunjukkan penguasaan ruang di suatu tempat. Jika suatu spesies mempunyai INP tinggi, maka spesies itu sangat berperan dalam mempengaruhi kestabilan habitatnya (Agustini et al., 2016; Warpur, 2018). Hasil analisis kerapatan relatif, penutupan relatif dan INP mangrove kategori pohon mempunyai nilai kisaran yang berbeda pada setiap stasiun pengamatan (Tabel 3).

Indeks Nilai Penting (INP) kategori pohon pada St 1 di duduki A.corniculatum yaitu sebesar 38,99-67,23\%. Tingginya INP Aegiceras corniculatum disebabkan nilai RDi (13,39-23,60\%) dan RKi (25,37-43,63\%) yang tinggi. Kondisi ini memberikan gambaran bahwa selain mempunyai jumlah tegakan banyak, spesies tersebut juga mempunyai diameter kecil dan hampir seragam. Hasil yang sama diperoleh Djohan, (2012); Hilmi et al., (2015) dan Ratini et al., (2016), bahwa Segara Anakan bagian 
timur, banyak ditemukan Aegiceras spp. dengan rata-rata diameter pohon kecil yaitu berkisar 6-10 $\mathrm{cm}$ dan sedang mengalami proses suksesi sekunder. Sehingga dapat memberikan harapan untuk pengembangan ekosistem mangrove di masa mendatang. Diduga mangrove di St 1 masih berumur muda sehingga memiliki diameter pohon yang kecil. Menurut Ananta et al., (2020); Rosadi et al., (2018) diameter pohon akan sejalan dengan umur, spesies dan perkembangan mangrove itu sendiri. INP A. corniculatum pada St 1 termasuk dalam kategori tinggi. Beberapa penggolongan INP yaitu INP > 42,66\% dikategorikan tinggi, INP antara 21,96-42,66\% dikategorikan sedang, dan INP $<21,96 \%$ dikategorikan rendah (Fachrul, 2008). Lebih lanjut Asman et al., (2020), menyatakan bahwa spesises yang mempunyai INP tinggi menunjukan adanya dominansi jenis. Akan tetapi, kondisi di stasiun ini berbeda dengan hutan mangrove di Desa Lembung Paseser, Kabupaten Bangkalan bahwa A.corniculatum mempunyai INP paling rendah yaitu 7,98\% (Ibrahim \& Muhsoni, 2020). Kerapatan rata-rata pohon mangrove di St 1 berdasarkan KepMen LH No. 51 (2004), masih dalam kondisi baik yaitu sebesar $3.559,26$ ind/ha.

Tabel 3. Kerapatan Relatif (RKi), Penutupan Relatif (RDi), Indeks Nilai Penting (INP) Pohon

\begin{tabular}{rlccc}
\hline Stasiun & \multicolumn{1}{c}{ Spesies } & RKi $(\%)$ & RDi $(\%)$ & INP $(\%)$ \\
\hline 1 & Aegiceras corniculatum & $25,37-43,63$ & $13,39-23,60$ & $38,99-67,23$ \\
& Bruguiera gymnorrhiza & $3,25-16,88$ & $15,50-24,02$ & $18,75-40,89$ \\
& Rhizophora mucronata & $2,23-27,27$ & $12,89-17,14$ & $15,11-44,41$ \\
& Rhizophora apiculata & $17,40-23,57$ & $13,71-22,75$ & $31,11-46,32$ \\
& Ceriops tagal & $0,97-10,62$ & $8,83-16,75$ & $9,8-24,71$ \\
& Avicennia alba & $12,01-16,81$ & $14,52-15,20$ & $27,21-31,33$ \\
& Sonneratia alba & 1,30 & 12,37 & 13,67 \\
& Sonneratia caseolaris & 0,88 & 16,86 & 17,74 \\
& Nypa fruticans & $3,25-12,39$ & & $3,25-12,39$ \\
\hline 2 & Avicennia alba & $5,86-7,23$ & $10,70-30,16$ & $16,84-37,25$ \\
& Bruguiera gymnorrhiza & $1,75-4,83$ & $17,47-25,21$ & $22,30-26,97$ \\
& Rhizophora mucronata & $1,38-8,81$ & $14,08-26,19$ & $15,46-34,99$ \\
& Rhizophora apiculata & $2,76-3,07$ & $16,81-19,86$ & $19,88-22,61$ \\
& Sonneratia caseolaris & 2,76 & 21,38 & 24,14 \\
& Aegiceras corniculatum & $17,11-33,02$ & $12,98-25,02$ & $38,15-54,81$ \\
& Nypa fruticans & $47,80-70,18$ & & $47,80-70,18$ \\
\hline 3 & Avicennia alba & $10,87-28,44$ & $10,87-28,44$ & $15,03-35,00$ \\
& Sonneratia caseolaris & $13,48-25,23$ & $16,96-29,23$ & $30,44-54,46$ \\
& Rhizophora apiculata & $9,57-10,22$ & $16,93-25,77$ & $26,49-35,86$ \\
& Rhizophora mucronata & $2,17-3,21$ & $15,27-28,08$ & $17,45-30,30$ \\
& Sonneratia alba & 32,44 & 23,88 & 56,32 \\
& Avicennia marina & 27,39 & 23,28 & 50,67 \\
& Aegiceras corniculatum & 3,48 & 9,77 & 13,25 \\
Nypa fruticans & $26,67-33,94$ & & $26,67-33,94$ \\
\hline
\end{tabular}

Pada St 2 INP tertinggi terdapat pada $N$. fruticans sebesar 47,80-70,18\%. INP vegetasi tersebut pada wilayah ini dikategorikan tinggi (INP>42,66\%). Tingginya INP pada spesies ini disebabkan nilai RKi yang tinggi meskipun nilai RDi nol. Hal tersebut menunjukan bahwa pada St 2 banyak terdapat tegakan $N$. fruticans dibandingkan vegetasi jenis lainnya. Banyaknya vegetasi pada $N$. fruticans diduga wilayah tersebut mengalami kerusakan ekosistem. Selain itu, pada stasiun ini banyak dijumpai bekas 
tebangan pohon vegetasi mayor oleh penduduk. Menurut (Anwari, et al., 2013), nipah (N. fruticans) merupakan salah satu jenis vegetasi mangrove yang dapat dijadikan indikator rusaknya ekosistem mangrove. Semakin banyak $N$. fruticans berarti bahwa kondisi ekosistem mangrove semakin rusak. Meskipun demikian berdasarkan KepMen LH No. 51 (2004), kondisi mangrove St 2 dalam kondisi baik dengan kerapatan ratarata 3.096,29 ind/ha.

Hasil penghitungan INP tertinggi pada St 3 terdapat pada $S$. alba yaitu 56,32\% dengan RDi sebesar 23,88\% dan RKi sebesar 32,44\%. INP tersebut termasuk dalam kategori tinggi. Selanjutnya INP tertinggi kedua diperoleh pada $S$. caseolaris yaitu bekisar 30,44-54,46\% dengan nilai RDi dan RKi berturut-turut 16,96-29,23\% dan 13,48-25,23\%. Tingginya INP pada $S$. alba disebabkan mempunyai nilai RKi yang tinggi dibanding $S$. caseolaris. Nilai RKi ini menggambarkan banyaknya tegakan vegetasi suatu jenis manggrove. Namun demikian RDi pada $S$. caseolaris memiliki kisaran yang lebih besar dibandingkan dengan $S$. alba. Kondisi ini menggambarkan bahwa $S$. caseolaris mempunyai ukuran diameter besar. Akan tetapi pada St 3, nilai RKi teringgi diperoleh $N$. fruticans. Keadaan ini menggabarkan bahwa pada St 3 terdapat banyak tegakan $N$. fruticans. Sedangkan pohon dengan ukuran yang besar terdapat pada $S$. caseolaris. Salah satu indikator yang mempengaruhi keberadaan S. caseolaris pada lokasi penelitian yaitu dapat tumbuh dengan kondisi salinitas rendah. Menurut Rosalina \& Rombe (2021), S. caesolaris dapat melakukan adaptasi pada kadar salinitas perairan sekitar $10 \%$ dan $S$. alba dengan kadar salinitas 2-18 \%o. INP S. alba menurut Fachrul, (2008), dikategorikan tinggi (INP > 42,66). Selain di Stasiun ini, INP tinggi pada $S$. alba juga diperoleh di Teluk Serewe, Pulau Lombok Nusa Teggara Barat (Irwansah et al., 2019) dan Desa Lembung Paseser, Kabupaten Bangkalan (Ibrahim \& Muhsoni, 2020). Nilai rata-rata kerapatan mangrove pada St 3 yaitu 2.492,59 ind/ha. Berdasarkan KepMen LH No. 51 (2004), kondisi mangrove di St 3 masih dalam kondisi baik.

Indeks Nilai Penting Vegetasi Mangrove Tingkat Sapling. Hasil analisis kerapatan relatif, penutupan relatif dan indeks nilai penting mangrove kategori sapling di kawasan Segara Anakan, mempunyai nilai kisaran yang berbeda pada setiap stasiun pengamatan (Tabel 4).

Tabel 4. Kerapatan Relatif (RKi), Penutupan Relatif (RDi), Indeks Nilai Penting (INP) Sapling

\begin{tabular}{clccc}
$\begin{array}{c}\text { Stasiun } \\
(\mathrm{St})\end{array}$ & \multicolumn{1}{c}{ Spesies } & $\mathrm{RKi}(\%)$ & $\mathrm{RDi}(\%)$ & $\mathrm{INP}(\%)$ \\
\hline 1 & Aegiceras corniculatum & $9,52-32,29$ & $16,48-31,21$ & $30,04-48,77$ \\
& Bruguiera gymnorrhiza & $3,81-34$ & $15,34-34,35$ & $25,70-68,35$ \\
& Rhizophora apiculata & $25-54$ & $2,71-34,44$ & $27,71-88,44$ \\
& Rhizophora mucronata & $5,21-30,48$ & $18,84-31,75$ & $36,97-49,32$ \\
& Avicennia alba & $9,38-15,24$ & $16,69-18,67$ & $26,06-33,91$ \\
& Ceriops tagal & 16,67 & 17,02 & 33,7 \\
\hline \multirow{2}{*}{2} & Avicennia alba & $14,29-20,51$ & $20,02-30,15$ & $40,54-44,43$ \\
& Bruguiera gymnorrhiza & 5,13 & 22,25 & 27,38 \\
& Rhizophora mucronata & $5,13-17,14$ & $19,64-35,61$ & $24,77-52,75$ \\
& Rhizophora apiculata & $10,26-28$ & $20,95-100$ & $31,20-128$ \\
& Sonneratia caseolaris & 7,69 & 17,14 & 24,83 \\
& Aegiceras corniculatum & 25,71 & 34,25 & 59,96 \\
& Nypa fruticans & $42,86-72$ & & $42,86-72$ \\
\hline & Avicennia marina & 4,55 & 17,28 & 21,83
\end{tabular}




\begin{tabular}{lccc} 
Sonneratia caseolaris & $11,82-28,72$ & $19,68-24,86$ & $31,49-53,58$ \\
Rhizophora mucronata & $12,73-17,86$ & $22,30-32,41$ & $35,03-50,27$ \\
Rhizophora apiculata & $2,73-17,02$ & $20,58-23,29$ & $23,31-40,31$ \\
Sonneratia alba & $18,18-24,47$ & $20,16-51,86$ & $38,34-76,32$ \\
Avicennia alba & 14,29 & 37,17 & 51,45 \\
Nypa fruticans & $29,79-50$ & & $29,79-50$ \\
\hline
\end{tabular}

Berdasarkan kategori sapling, INP tertinggi St 1 terdapat pada spesies $R$. apiculata yaitu 27,71-88,44\%. Tingginya INP $R$. Apiculata disebabkan RKi (25-54\%) yang tinggi. Namun demikian, nilai RDi pada St 1 relatif berukuran sama. Kondisi ini menggambarkan bahwa sapling $R$. apiculata mempunyai jumlah tegakan banyak dengan ukuran diameter seragam. Pada St 2, INP tertinggi kategori sapling terdapat pada jenis $R$. apiculata $(31,20-128 \%)$. Tingginya INP vegetasi tersebut dikarenakan tingginya nilai RKi (10,26-100\%) dan RDi (20,95-100\%). Menurut Ananta et al., (2020) dan Anwari et al., (2013) vegetasi mangrove kategori sapling pada Segara Anakan bagian tengah dan timur didominansi jenis $R$. apiculata. Kondisi ini serupa dengan hutan mangrove Kuala IDI Kabupaten Aceh Timur, bahwa INP sapling tertinggi terdapat pada spesies $R$. apiculata sebesar 191,97\% (Parmadi et al., 2016). Hal ini diduga jenis substrat lumpur berpasir pada lokasi penelitian sesuai dengan kehidupannya. Menurut Upara et al., (2021), R. apiculata banyak dijumpai pada substrat lumpur berpasir. Ditambahkan oleh Zulkarnain et al., (2018), tingginya INP jenis Rhizhopora sp di Pulau Kabaena, Sulawesi Tenggara disebabkan jenis tersebut mempunyai daya adaptasi, daya kompetisi dan kemampuan reproduksi yang lebih baik dibandingkan dengan tumbuhan yang lain dalam satu wilayah. $R$. apiculata pada St 1 dan St 2 memiliki peranan penting di kawasannya. Menurut Sutisno (1993) dalam Irwansah et al., (2019), tingkatan vegetasi sapling suatu jenis dapat dikatakan berperan jika INP $>10 \%$.

INP sapling pada St 3 tertinggi terdapat pada $S$. alba yaitu 38,34-76,32\% dengan RDi sebesar 20,16-51,86\% dan RKi sebesar 18,18-24,47\% Selanjutnya INP tertinggi kedua diperoleh pada $S$. caseolaris yaitu bekisar 31,49-53,58\% dengan nilai RDi dan RKi berturut-turut $19,68-24,86 \%$ dan $11,82-28,72 \%$. Tingginya INP pada $S$. alba disebabkan mempunyai nilai RDi yang lebih tinggi dibanding $S$. caseolaris. Nilai RDi ini menggambarkan diameter $S$. alba lebih besar dibanding $S$. caseolaris. Namun demikian, nilai RKi $S$. alba lebih kecil dibanding $S$. caseolaris. Kondisi ini menggambarkan sapling $S$. alba mempunyai diameter besar dengan jumlah tegakan yang lebih sedikit dibanding dengan $S$. caseolaris. Diduga kemampuan adaptasi $S$. Alba terhadap salinitas rendah. Menurut Rosalina \& Rombe, (2021), S. alba dapat tumbuh dengan kadar salinitas 2-18\%o. Kondisi wilayah ini serupa dengan hutan mangrove Desa Tabulo Selatan, Provinsi Gorontalo (Antu et al., 2015) dan Teluk Serewe Pulau Lombok Nusa Tenggara Barat (Irwansah et al., 2019) yaitu INP tertinggi sapling diperoleh jenis $S$. alba dan $S$. caseolaris. Pada St 3 S. Alba memiliki peranan penting di wilayahnya. Tingkatan vegetasi sapling dapat dikatakan berperan jika INP > 10\% (Sutisno, (1993) dalam Irwansah et al., 2019).

Indeks Nilai Penting Vegetasi Mangrove Tingkat Semai. Hasil analisis kerapatan relatif, frekuensi relatif dan indeks nilai penting mangrove kategori semai di kawasan Segara Anakan, mempunyai nilai kisaran yang berbeda pada setiap stasiun pengamatan (Tabel 5). 
Tabel 5. Nilai Kerapatan Relatif (RKi), Frekuensi Relatif (RFi), Indeks Nilai Penting (INP) Semai

\begin{tabular}{clccc}
\hline Stasiun & \multicolumn{1}{c}{ Spesies } & RFi $(\%)$ & RKi $(\%)$ & Nilai Penting \\
\hline 1 & Derris heterophylla & $14,29-41,67$ & $23,40-65,63$ & $37,69-107,29$ \\
& Acanthus ilicifolius & $13,33-42,86$ & $14,04-25,53$ & $27,37-68,39$ \\
& Rhizophora apiculata & $8,33-28,57$ & $4,69-25,53$ & $13,02-54,10$ \\
& Rhizophora mucronata & $13,33-14,29$ & $7,02-44,68$ & $20,35-58,97$ \\
& Ceriops tagal & 13,33 & 8,77 & 22,11 \\
& Bruguiera gymnorrhiza & $13,33-16,67$ & $9,38-10,53$ & $23,86-26,04$ \\
& Avicennia alba & 13,33 & 14,04 & 27,37 \\
& Nypa fruticans & 14,29 & 4,26 & 18,54 \\
\hline 2 & Derris heterophylla & $23,08-41,67$ & $33,75-47,14$ & $56,83-88,81$ \\
& Acanthus ilicifolius & $20,00-41,67$ & $26,87-43,75$ & $46,87-83,10$ \\
& Aegiceras corniculatum & $15,38-20,00$ & $10-11,94$ & $25-31,94$ \\
& Nypa fruticans & $16,67-30,00$ & $11,43-14,93$ & $28,10-44,93$ \\
\hline 3 & Derris heterophylla & $16,67-33,33$ & $13,16-54,79$ & $29,82-88,13$ \\
& Acanthus ilicifolius & $25,00-33,33$ & $27,40-50,00$ & $60,73-83,33$ \\
& Sonneratia alba & 16,67 & 25,00 & 41,67 \\
& Avicennia alba & $6,67-33,33$ & $2,70-17,81$ & $9,37-51,14$ \\
& Rhizophora mucronata & 6,67 & 4,05 & 10,72 \\
& Nypa fruticans & $16,67-26,67$ & $6,58-17,57$ & $23,25-44,23$ \\
\hline & & & & \\
& & &
\end{tabular}

Pada kriteria semai, INP tertinggi di semua stasiun terdapat pada jenis $D$. heterophylla. St 1 sebesar 37,69-107,29\%, St 2 sebesar 56, 83-88,81\% dan St 3 sebesar $29,82-88,13 \%$. INP tertinggi kedua diduduki spesies A. ilicifolius yaitu 27,37-68,39\% di St 1, 46,87-83,10\% di St 2 dan 60,73-83,33\% di St 3. Hal ini menunjukan bahwa semua stasiun pengamatan vegetasi semai didominansi oleh $D$. heterophylla dan A. ilicifolius. Penelitian serupa dilakukan Anwari et al., (2013); Djohan, (2012) di Wilayah Segara Anakan Cilacap, diperoleh hasil bahwa semai didominansi oleh D. heterophylla dan $A$. ilicifolius. Kedua spesies tersebut dapat tumbuh dengan cepat pada lahan yang terbuka, sehingga dapat menjadi kompetitor mangrove sejati dalam mendapatkan ruang dan nutrisi. Ditambahkan oleh Anggraini et al., (2015), D. heterophylla dan A. ilicifolius dapat dijadikan indikator kerusakan mangrove. Berdasarkan perannya $D$. heterophylla dan A. ilicifolius memiliki tingkatan berperanan pada wilayahnya. Menurut Sutisno (1993) dalam Irwansah et al., (2019), bahwa tingkatan vegetasi semai suatu jenis dapat dikatakan berperan jika INP > 10\%.

Indeks Keanekaragaman (H'). Hasil indeks keanekaragaman hutan mangrove Segara Anakan Cilacap berdasarkan kategori pohon, sapling dan semai tertera pada tabel 6. Berdasarkan hasil penelitian rata-rata indeks keanekaragaman $\left(\mathrm{H}^{\prime}\right)$ kelas pohon pada St 1 sebesar 1,66; St 2 sebesar 1,14; St 3 sebesar 1,49. Pada kelas sapling St 1, St 2 dan St 3 berturut-turut 1,31; 1,09 dan 1,42. Sedangkan pada kelas semai St 1 adalah 1,42, St 2 dan St 3 yaitu 1,15 dan 0,90. Pada semua stasiun pengamatan indeks keanekaragaman termasuk dalam kategori sedang, kecuali pada kelas semai pada St 3, termasuk dalam kategori rendah-sedang. Tingkat keanekaragaman sedang menunjukan kondisi ekosistem yang cukup seimbang dengan tekanan ekologisnya sehingga mengakibatkan penyebaran jenis mangrove cukup merata. Sedangkan tingkat keanekaragaman yang rendah menunjukan bahwa penyebaran individu tiap jenis tidak merata. Hal ini disebabkan semakin kecil jumlah spesies dan ada beberapa individu 
yang dominan, mengakibatkan terjadinya ketidakstabilan ekosistem. Diduga lokasi St 3 merupakan muara sungai, sehingga proses sedimentasi ikut mempengaruhi kestabilan ekosistem. Selain itu, pada St 3 dekat dengan pemukiman penduduk. Oleh karena itu limbah buangan serta aktifitas penduduk dalam memanfaatkan hutan mangrove turut mempengaruhi keseimbangan ekosistem. Meskipun demikian, indeks keanekargaman di Segara anakan lebih tinggi dibanding Kabupaten Sampang, Madura berkisar 0,05-0,47 (Rosadi et al., 2018) dan Desa Tabula, Provinsi Gorontalo berkisar 0-0,69 (Antu et al., 2015).

Tabel 6. Nilai Keanekaragaman Berdasarkan Tingkat Pertumbuhan Mangrove

\begin{tabular}{cccc}
\hline \multirow{2}{*}{ St } & \multicolumn{3}{c}{ Keanekaragaman } \\
\cline { 2 - 4 } & Pohon & Sapling & semai \\
\hline 1 & 1,66 & 1,31 & 1,42 \\
2 & 1,14 & 1,09 & 1,15 \\
3 & 1,49 & 1,42 & 0,90 \\
Kriteria & sedang & Sedang & Rendah-sedang \\
\hline
\end{tabular}

Kondisi Lingkungan Ekosistem Mangrove. Pengukuran kualitas air dan sedimen dilakukan untuk mengetahui karakteristik lingkungan hutan mangrove Segara Anakan, Cilacap. Hasil pengukuran kualitas air dan sedimen dapat dilihat pada tabel 7.

Tabel 7. Pengukuran Parameter Kualitas Air dan Sedimen

\begin{tabular}{llll}
\hline Parameter & ST 1 & ST 2 & ST 3 \\
\hline suhu air & $27-29,5$ & $28-30$ & $28-29,9$ \\
salinitas & $10-15 \%$ o & $9-10 \%$ o & $4-8 \%$ o \\
oksigen terlarut & $1,1-2,2$ & $1,2-2$ & $1,5-2,4$ \\
ph tanah & $7-7,1$ & $7-7,2$ & $6,5-7,9$ \\
ph air & $7,15-7,18$ & $6-8,1$ & $7,12-8,37$ \\
TSS & $15,1-16,3$ & $14,8-50,33$ & $21,3-65,3$ \\
N total tanah & $0,192-0,236$ & $0,04-0,152$ & $0,167-0,36$ \\
C-organik tanah & $0,509-2,274$ & $0,48-3,019$ & $1,103-3,324$ \\
Posfat tanah & $0,086-0,111$ & $0,075-0,087$ & $0,045-0,067$ \\
\hline
\end{tabular}

Suhu perairan memegang peranan yang sangat penting bagi pertumbuhan mangrove. Selama penelitin diperoleh kisaran suhu $27-29,5^{\circ} \mathrm{C}$ pada $\mathrm{St} 1,28-30^{\circ} \mathrm{C}$ pada St 2 dan 28-29,9 ${ }^{\circ} \mathrm{C}$ pada St 3. Kondisi ini sama dengan suhu perairan di Kawasan Konservasi Mangrove dan Bekantan Kota Tarakan (KKMB) berkisar antara $27-29{ }^{\circ} \mathrm{C}$ (Yulma et al., 2018). Menurut KepMen LH No. 51 (2004), nilai suhu yang sesuai dengan pertumbuhan mangrove adalah $28-32^{\circ} \mathrm{C}$. Hal ini berarti bahwa suhu perairan Laguna Segara Anakan mendukung pertubuhan mangrove.

Pengkuran salinitas pada St 1, St 2 dan St 3 berturut-turut yaitu 10-15\%, 9-10\%o dan 4-8\%o. Nilai salinitas pada St 3 lebih rendah dibanding lokasi lainnya karena daerah tersebut merupakan muara Sungai Citanduy, Sungai Cibereum dan Sungai Cikonde. Berbeda dengan kadar salinitas pada St 1 paling tinggi diantara yang lainnya disebabkan karena lokasi penelitian lebih mendekati laut. Penelitian serupa dilakukan oleh Ardli et al., (2015), bahwa kisaran nilai salinitas pada Segara anakan bagian barat dan tengah berkisar 1-5\%. Meskipun demikian, berdasarkan baku mutu untuk biota laut, kawasan 
hutan mangrove Segara Anakan masih baik untuk pertumbuhan mangrove. Menurut KepMen LH No. 51 (2004) baku mutu kawasan mangrove memiliki kadar salinitas alami sampai dengan 34\%o.

Dissolved Oxygen $(D O)$ atau kadar oksigen terlarut pada lokasi penelitian berkisar 1,1-2,2 ppm pada St 1, pada St 2 sebesar 1,2-2 ppm dan 1,5-2,4 ppm pada St 3 . Berdasarkan KepMen LH No. 51 (2004) nilai DO yang dianjurkan yakni > 5 mg/l. Oksigen terlarut pada lokasi penelitian berada dibawah batas baku mutu. Rendahnya nilai oksigen terlarut juga terdapat pada ekosistem mangrove Desa Socah, BangkalanMadura yaitu 3,65-4 ppm (Salafiyah \& Insafitri, 2020). Akan tetapi, kecilnya kadar oksigen terlarut pada ekosistem ini dapat diatasi oleh vegetasi mangrove dengan cara mempunyai sistem perakaran yang khas.

Derajat keasaman $(\mathrm{pH})$ tanah pada St 1 sebesar 7-7,1, pada St 2 sebesar 7-7,2 dan pada St 3 sebesar 6,5-7,9. Nilai $\mathrm{pH}$ tanah di lokasi penelitian tidak berbeda jauh dengan wilayah Pantai Jenu Tuban dan Wonorejo Surabaya yaitu berkisar antara 6,7 7,9 (Pradipta et al., 2021). Menurut Fajar et al., (2013) pH tanah berkisar antara 6-7 merupakan $\mathrm{pH}$ yang sesuai untuk pertumbuhan mangrove. Hal ini berarti bahwa kisaran $\mathrm{pH}$ tanah pada semua stasiun pengamatan masih tergolong baik untuk pertumbuhan mangrove.

Berdasarkan hasil penelitian, kisaran nilai pH air untuk St 1 yaitu 7,15-7,18, pada St 2 dan St 3 berturut-turut 6-8,1 dan 7,12-8,37. Pengukuran $\mathrm{pH}$ air di kawasan ini pernah dilakukan Hilmi et al., (2019) dengan kisaran hasil 5,7-7,9. Berdasarkan KepMen LH No. 51, (2004), nilai pH air di daerah hutan mangrove Segara Anakan masih sesuai dengan baku mutu untuk wilayah mangrove yaitu 7-8,5.

Kisaran Nilai Total Suspended Solid (TSS) pada St 1 sebesar 15,1-16,3 mg/l, St 2 sebesar 14,8-50,33 mg/l dan St 3 sebesar 21,3-65,3 mg/l. Nilai TSS tertinggi diperoleh pada St 3, hal ini disebabkan karena lokasi penelitian terletak pada muara dan dekat dengan pemukiman penduduk. Kondisi tersebut hampir sama dengan yang diperoleh pada wilayah hutan mangrove Pulau Nain dan Pulau Mantehage diperoleh nilai TSS 26,6-37,92 mg/l (Schaduw, 2018). Menurut baku mutu air laut untuk biota laut KepMen LH No. 51, (2004) nilai TSS < 80 mg/l. Nilai TSS Segara Anakan termasuk dalam kategori baik.

Kandungan N total tanah pada St 1 berkisar 0,192-0,236\%; St 2 berkisar 0,040,152\% dan St 3 berkisar 0,167-0,36\%. Kandungan N total di Segara Anakan lebih rendah dibanding daerah Lebiti, Kabupaten TojoUna-Una yaitu 0,38-0,89\% (Arsad et al., 2017) dan daerah Aluh-Aluh Besar, Kabupaten Banjar 0,34-0,49\% (Hardiansyah \& Noorhidayati, 2020). Rendahnya $\mathrm{N}$ total pada lokasi penelitian diduga pada saat pengambilan sampel tanah hanya pada kedalaman $20 \mathrm{~cm}$ (permukaan). Menurut Arsad et al., (2017) dan Dewi et al., (2017) kandungan $\mathrm{N}$ total tanah lapisan atas lebih rendah dibandingkan pada lapisan bawah $(30-60 \mathrm{~cm})$.

Berdasarkan hasil penelitian diperoleh nilai C-organik tanah St 1 sebesar 0,5092,274\%; St 2 dan St 3 berturut-turut 0,48-3,019\% dan 1,103-3,324\%. Kawasan Segara Anakan lebih rendah dibanding daerah daerah Lebiti, Kabupaten TojoUna-Una yaitu 2,08- 9,30\% (Arsad et al., 2017) dan daerah Aluh-Aluh Besar, Kabupaten Banjar 2,8925,02\% (Hardiansyah\&Noorhidayati, 2020). Namun demikian, menurut Hardjowigeno, (2003) substrat dapat dikatakan memiliki kesuburan tinggi apabila kandungan Corganiknya $>3 \%$ dan menjadi sangat tinggi apabila $>5 \%$ C-organik. Pada St 2 dan St 3 memiliki kandungan C-orgaik tinggi diduga memiliki ukuran pohon yang besar, sehingga kandungan serasahnya lebih tinggi dibanding St 1 . 
Nilai fosfat tanah pada St 1 sebesar 0,086-0,111\%; St 2 sebesar 0,075-0,087\% dan St 3 yaitu 0,045-0,067\%. Menurut Effendi, (2003), tiga penggolongan nilai fosfat yaitu rendah (0-0,02\%), sedang (0,021-0,05\%) dan tinggi (0,051-0,1\%). St 1 dan St 2 termasuk dalam kategori tinggi, St 3 terasuk dalam kategori sedang dan tinggi. Diduga tingginya nilai fosfat berasal dari pelapukan dan limbah dari daratan. Menurut Yahra et al., (2020), hasil proses dekomposisi tumbuhan ataupun hewan yang telah mati serta buangan limbah daratan (domestik, industri, pertanian, peternakan) merupakan salah satu penyumbang unsur hara fosfat disuatu wilayah. Meskipun demikian, nilai pospat di hutan mangrove Segara Anakan lebih tinggi dibandingkan Pantai Jenu Tuban dan Ecotourism Wonorejo Surabaya berkisar antara 0,0021-0,043 ppm (Pradipta et al., 2021).

\section{SIMPULAN}

Berdasarkan hasil penelitian di hutan mangrove Segara Anakan, Cilacap. Ditemukan 12 spesies mangrove yang terdiri dari 4 famili mangrove mayor, 1 famili mangrove minor dan 2 famili mangrove asosiasi. Secara umum, vegetasi pohon mangrove pada Segara Anakan bagian timur didominansi oleh Aegiceras corniculatum dengan INP berkisar 38,99-67,23\%, bagian tengah didominansi oleh Nypa fruticans dengan INP berkisar 47,80-70,18\% dan bagian barat didominansi oleh Sonneratia alba dengan INP 56,32\%. Indeks Keanekaragaman $\left(\mathrm{H}^{\circ}\right)$ pohon, sapling dan semai pada ketiga lokasi penelitian termasuk dalam kategori sedang, kecuali kelas semai pada bagian barat lokasi penelitin termasuk dalam kategori rendah. Keadaan ekosistem mangrove Segara Anakan tergolong masih baik dengan didukung kualitas lingkungan yang masih sesuai dengan kriteria baku mutu KepMen. LH No. 51 Tahun 2004. Dengan adanya penelitian ini diharapkan dapat dijadikan referensi bagi pemerintah dan warga setempat untuk melestarikan ekosistem mangrove Segara Anakan menjadi lebih baik.

\section{UCAPAN TERIMAKASIH}

Penulis menyampaikan terimakasih kepada Kemenristek Brin atas Pendanaan Hibah anggaran tahun 2021. Ucapan terimakasih juga tertuju kepada semua pihak yang telah ikut membantu dalam penelitian atas bantuan tenaga, fikiran dan dukungannya.

\section{DAFTAR RUJUKAN}

Agustini, N. T., Ta'alidin, Z., \& Purnama, D. (2016). Struktur Komunitas Mangrove Di Desa Kahyapu Pulau Enggano. Jurnal Enggano, 1(1), 19-31. https://doi.org/10.31186/jenggano.1.1.19-31

Ananta, R. R., Soenardjo, N., \& Pramesti, R. (2020). Karakteristik Mangrove Di Muara Sungai Timur Kawasan Laguna Segara Anakan, Kabupaten Cilacap Jawa Tengah. Journal of Marine Research, 9(4), 416-422. https://doi.org/10.14710/jmr.v9i4.28816

Anggraini, N., Adawiah, S. W., Purwanto, A. D., \& Parwati, E. (2015). Analisis Spektral Reflektan Mangrove di Segara Anakan Dengan Menggunakan Data Penginderaan Jauh. Prosiding Pertemuan Ilmiah Tahunan XX 2015 Analisis, 598605.

Antu, Y. R., Sahami, F. M., \& Hamzah, S. N. (2015). Keanekaragaman jenis dan indeks nilai penting mangrove di Desa Tabulo Selatan Kecamatan Mananggu Kabupaten Boalemo Provinsi Gorontalo. Jurnal Ilmiah Perikanan Dan Kelautan, 3(1), 11-15.

Anwari, M. S., Sunarto, Dulbahri, \& Hadisusanto, S. (2013). Pengaruh Struktur 
Vegetasi Terhadap Kelimpahan Kerang Bakau (Polymesoda erosa lightfoot 1786) Pada Musim Kemarau Di Kawasan Hutan Mangrove Segaraanakan Cilacap. Tengkawang, Jurnal Ilmu Kehutanan, 3(1), 33-45. https://doi.org/http://dx.doi.org/10.26418/jt.v3i1.10355

Ardli, E. R., Widyastuti, A., \& Yani, E. (2015). Kajian Perubahan Bioekologi pada Restorasi Ekosistem Mangrove di Segara Anakan Cilacap. Biosfera, 32(1), 19. https://doi.org/10.20884/1.mib.2015.32.1.291

Arsad, W. M., Toknok, B., \& Korja, I. N. (2017). Sifat Kimia Tanah di Bawah Vegetasi Mangrove di Desa Lebiti Kecamatan Togean Kabupaten Tojo Una - Una. J. ForestSains, 15(1), 22-27.

Asman, I., Sondak, C. F. A., Schaduw, J. N. W., Kumampung, D. R. H., Ompi, M., \& Sambali, H. (2020). Struktur Komunitas Mangrove Di Desa Lesah, Kecamatan Tagulandang, Kabupaten Sitaro. Jurnal Pesisir Dan Laut Tropis, 8(2), 48. https://doi.org/10.35800/jplt.8.2.2020.28769

Bengen, D. G. (2000). Sinopsis Teknik Pengambilan Contoh dan Analisis Data Biofisik Sumberdaya Pesisir. Pusat Kajian Sumberdaya Pesisir dan Lautan. Fakultas Peikanan dan Ilmu Kelautan. Institut Pertanian Bogor. 85 hal.

Dewi, N. N. D. K., Dirgayusa, I. G. . P., \& Suteja, Y. (2017). Kandungan Nitrat dan Fosfat Sedimen serta Keterkaitannya dengan Kerapatan Mangrove di Kawasan Mertasari di Aliran Sungai TPA Suwung Denpasar, Bali. Journal of Marine and Aquatic Sciences, 3(2), 180. https://doi.org/10.24843/jmas.2017.v3.i02.180-190

Dewi, R., Zainuri, M., Anggoro, S., \& Winanto, T. (2016). Analisis Perubahan Tata Guna Lahan Kawasan Segara Anakan Selama Periode Waktu (1978-2016) Menggunakan Satelit Landsat Multitemporal. Omni-Akuatika, 12(3), 144-150.

Djohan, T. S. (2012). Distribution And Abundance Of Mangrove Vegetation The Distrubed Ecosystem of Segara anakan, Central Java. Jurnal Manusia Dan Lingkungan, 19(3), 294-302.

Dwininta, A. C., \& Hartono. (2017). Perubahan Hutan Mangrove Tahun 2000-2015 Di Segara Anakan Kab. Cilacap Jawa Tengah Menggunakan Citra Landsat 7 Etm+ Dan 8 Oli. Jurnal Bumi Indonesia, 6(1), 1-10. http://lib.geo.ugm.ac.id/ojs/index.php/jbi/article/view/807

Effendi, H. (2003). Telaah Kualitas Air Bagi Pengelolaan Sumberdaya dan Lingkungan Perairan. Kanisius. Yogyakarta.258 hal.

Fachrul, M. F. (2008). Metode Sampling Bioekologi. Bumi Aksara. 208 hal.

Fajar, A., Oetama, D., \& Afu, A. (2013). Studi Kesesuaian Jenis untuk Perencanaan Rehabilitasi Ekosistem Mangrovedi Desa Wawatu Kecamatan Moramo Utara Kabupaten Konawe Selatan. Jurnal Mina Laut Indonesia, 03(12), 164-176.

Fitriah, E., Maryuningsih, Y., Chandra, E., \& Mulyyani, A. (2013). Studi Analisis Pengelolaan Hutan Mangrove Kabupaten Cirebon. Jurnal Scientiae Educatia, 2(2), $1-18$.

Hardiansyah, \& Noorhidayati. (2020). Keanekaragaman Jenis Pohon pada Vegetasi Mangrove di Pesisir Desa Aluh-Aluh Besar Kabupaten Banjar. Wahana-Bio: Jurnal Biologi Dan Pembelajarannya, 12(2), 71-85. https://doi.org/10.20527/wb.v12i2.9540

Hardjowigeno, S. (2003). Klasifikasi Tanah dan Pedogenesis. Jakarta: Akademika Pressindo.

Hilmi, E, Sari, L. K., \& Amron, A. (2019). Distribusi Sebaran Mangrove Dan Faktor Lingkungan Pada Ekosistem Mangrove Segara Anakan Cilacap. Prosiding 
Seminar Nasional Dan Call for Papers "Pengembangan Sumber Daya Perdesaan Dan Kearifan Lokal Berkelanjutan IX”, November, 23-33. http://jurnal.lppm.unsoed.ac.id/ojs/index.php/Prosiding/article/view/1023

, Kartika Sari, L., Mahdiana, A., \& Rani Samudra, S. (2020). Status and Rehabilittion Pattern of Mangrove Ecosystem in the Eastern of Segara Anakan Cilacap. Jurnal READ (Research of Empowerment and Development), 1(1), 19. https://doi.org/10.20884/1.read.2020.1.1.2407

Siregar, A. S., \& Febryanni, L. (2015). Struktur Komunitas, Zonasi Dan Keanekaragaman Hayati Vegetasi Mangrove Di Segara Anakan Cilacap. OmniAkuatika, 11(2), 20-32. https://doi.org/10.20884/1.oa.2015.11.2.36

Ibrahim, A., \& Muhsoni, F. F. (2020). Estimasi Stok Karbon Pada Ekosistem Hutan Mangrove Di Desa Lembung Paseser, Kecamatan Sepuluh, Kabupaten Bangkalan. Juvenil, 1(4), 498-507. http://doi.org/10.21107/juvenil.v1i4.8947

Irwan, Irwansyah, Surachmat, A., Khairul, J., Supryady, \& Lasikada, H. (2019). Kajian Kondisi dan Komposisi Vegetasi Hutan Mangrove di Wilayah Pesisir Kabupaten Bone. Prosiding Simposium Nasional Kelautan Dan Perikanan VI Universitas Hasanuddin, 157-166.

Irwansah, Sugiyarto, \& Mahajoeno, E. (2019). Struktur Komunitas Ekosistem Mangrove Di Teluk Serewe Pulau Lombok Nusa Tenggara Barat. Bioeksperimen, 5(2), 126-130. https://doi.org/10.23917/bioeksperimen.v5i2.2795

Koswara, S. D., Ardli, E. R., \& Yani, E. (2017). The Monitoring of Mangrove Vegetation Community Structure in Segara Anakan Cilacap for the Period of 2009 and 2015. Scripta Biologica, 4(2), 113. https://doi.org/10.20884/1.sb.2017.4.2.414

Keputusan Menteri Negara Lingkungan Hidup. (2004). Keputusan Menteri Lingkungan Hidup No 51 Tahun 2004 Tentang Baku Mutu Air Laut, 1-13.

Mishbach, I., Pribadi, R., \& Santoso, A. (2018). Kajian Kawasan Rehabilitasi Mangrove Di Desa Ketitang Wetan dan Desa Raci Kecamatan Batangan Kabupaten Pati. Journal of Marine Research, 7(1), 69-78. https://ejournal3.undip.ac.id/index.php/jmr/article/view/25889

Noor, Y. R., Khazali, M., \& Suryadiputra, I. N. N. (2006). Paduan Pengenalan Mangrove di Indonesia (2nd ed.). PHA/WI-IP.

Parmadi, E. H. J., Dewiyanti, I., \& Karina, S. (2016). Indeks Nilai Penting Vegetasi Mangrove Di Kawasan Kuala Idi , Kabupaten Aceh Timur. Jurnal Ilmiah Mahasiswa Kelautan Dan Perikanan Unsyiah Volume, 1(1), 82-95.

Pradipta, N., Alamsjah, M. A., \& Masithah, E. D. (2021). Study Of Nitrogen (N) And Phosphorus (P) In The Land Of Mangrove Sediments In Ecotourism Area Wonorejo Surabaya And Coastal Area Of Jenu Tuban. IOP Conference Series: Earth and Environmental Science, 679(1), 1-6. https://doi.org/10.1088/1755$1315 / 679 / 1 / 012048$

Pratama, L. W., \& Isdianto, A. (2017). Pemetaan Kerapatan Hutan Mangrove Di Segara Anakan, Cilacap, Jawa Tengah Mengunakan Citra Landsat 8 Di Lembaga Penerbangan Dan Antariksa Nasional (Lapan), Jakarta. Jurnal Floratek, 12(1), 5761.

Ratini, Sulistyantara, B., \& Budiarti, T. (2016). Perencanaan Konservasi Ekosistem Mangrove Desa Ujung Alang Kecamatan Kampung Laut Kabupaten Cilacap. Jurnal Silvikultur Tropika, 7(2), 108-114.

Rosadi, A., Ario, R., \& Rudhi, P. (2018). Struktur Dan Komposisi Vegetasi Mangrove Di Kabupaten Sampang, Pulau Madura, Provinsi Jawa Timur. Journal of Marine 
and Aquatic Sciences, 7(3), 212-218.

Rosalina, D., \& Rombe, K. H. (2021). Struktur dan Komposisi Jenis Mangrove di Kabupaten Bangka Barat. Jurnal Airaha, 10(01), 99-108.

Salafiyah, L., \& Insafitri. (2020). Analisa Kandungan Nutrien (Fosfat Dan Nitrat) Pada Serasah Mangrove Jenis Rhizophora Sp. Dan Avicennia Sp. Di Desa Socah, Bangkalan-Madura.Juvenil,1(2),168-179. https://doi.org/10.21107/juvenil.v1i2.7571

Schaduw, J. N. (2018). Distribusi Dan Karakteristik Kualitas Perairan Ekosistem Mangrove Pulau Kecil Taman Nasional Bunaken. Majalah Geografi Indonesia, 32(1), 40. https://doi.org/10.22146/mgi.32204

Suryono, C. A. (2015). Ekologi Mangrove Di Segara Anakan Ditinjau dari Aspek: Kelimpahan dan Distribusi. Jurnal Kelautan Tropis, 18(1), 20-27. https://doi.org/10.14710/jkt.v18i1.510

Tefarani, R., Tri Martuti, N. K., \& Ngabekti, S. (2019). Keanekaragaman Spesies Mangrove dan Zonasi di Wilayah Kelurahan Mangunharjo Kecamatan Tugu Kota Semarang. Life Science, 8(1), 41-53. https://doi.org/10.15294/lifesci.v8i1.29989

Upara, U., KUsen, J. D., Sondak, Calvyn, F. ., Schaduw, J. N. W., Tilaar, S. O., \& Lasabuda, R. (2021). Struktur Komunitas Dan Zonasi Vegetasi Mangrove Desa Darunu Kecamatan Wori Kabupaten Minahasa Utara. Jurnal Pesisir Dan Laut Tropis, 9(1), 65-73.

Warpur, M. (2018). Struktur vegetasi hutan mangrove di Kampung Kunef Distrik Supiori Selatan Kabupaten Supiori. Prosiding Seminar Nasional Edusaintek FMIPA UNIMUS, 71-76.

Yahra, S., Harahap, Z. A., Yusni, E., \& Leidonald, R. (2020). Analisis Kandungan Nitrat Dan Fosfat Serta Keterkaitannya Dengan Kerapatan Mangrove Di Pantai Labu Kabupaten Deli Serdang. Jurnal Enggano, 5(3), 15-21. https://doi.org/https://doi.org/10.31186/jenggano.5.3.350-366

Yulma, Salim, G., \& Sampe, Y. (2018). Analisis Bahan Organik Nitrogen (N) Dan Fosfor (P) Pada Sedimen Di Kawasan Konservasi Mangrove Dan Bekantan (Kkmb) Kota Tarakan. Jurnal Borneo Saintek, 1(2), 75-82. www.ojs.borneo.ac.id

Zulkarnain, Bana, S., \& Indriyani, L. (2018). Potensi Ekologi Mangrove Tingkat Pohon dan Pancang Pulau Kabaena Kabupaten Bombana Sulawesi Tenggara. Ecogreen, 4(1), 63-71. 